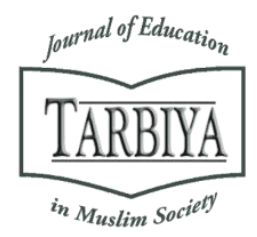

Available online at TARBIYA: Journal of Education in Muslim Society Website:

http://journal.uinjkt.ac.id/index.php/tarbiya

TARBIYA: Journal of Education in Muslim Society, 7(1), 2020, 133-141

\title{
IMPROVING STUDENTS' SCIENTIFIC LITERACY THROUGH THE CYCLE-BASED LEARNING MODEL
}

\author{
Atikah Syamsi*, Zulela M.S., Yufiarti \\ Universitas Negeri Jakarta, Indonesia \\ E-mail: AtikahSyamsi_7527167807@mhs.unj.ac.id
}

Received: $19^{\text {th }}$ April 2020; Revised: $26^{\text {th }}$ May 2020; Accepted: $29^{\text {th }}$ June 2020

\begin{abstract}
The study is to provide an alternative science learning model of an elementary school that can invite students to improve science literacy. As observations and questionnaires of researchers in a preliminary study at two elementary schools in the city of Cirebon, West Java, it was found that based on the average results of the initial analysis of scientific literacy tests of students from the two schools, an average of $85.7 \%$ showed negative results with the ability to answer the practice of science questions in the form of literacy, which means that students have not been able to answer literacy questions test. The research method uses model development the ASSURE development model starting with Student analysis; setting goals; choose a method, media / material, use media \& material; activating student involvement as well as evaluations \& revisions developed by Sharon Smaldino. As for the preliminary study conducted by analyzing 5th-grade students of Madrasah Ibtidaiyah (MI) PGM and Madrasah Ibtidaiyah (MI) An-Nur Cirebon as samples and also observing teachers from the two schools, so this research produces a SIBELPOLEN model for science learning, which consists of teaching syntax, teacher roles, support system, accompaniment impact, instructional impact and designing lesson plans that can improve

Science literacy competence of elementary school students.
\end{abstract}

Keywords: learning cycle; elementary school; positive learning environment

\section{Abstrak}

Penelitian ini bertujuan untuk memberikan alternatif model pembelajaran Ilmu Pengetahuan Alam (IPA) di sekolah dasar dalam meningkatkan literasi sains pada siswa. Hasil observasi dan angket peneliti dalam studi pendahuluan di dua Sekolah Dasar di Kota Cirebon Jawa Barat diketahui bahwa berdasarkan rata-rata hasil analisis awal tes literasi sains siswa dari dua sekolah tersebut rata-rata 85,7\% menunjukkan hasil negatif dengan kemampuan menjawab soal latihan soal IPA berupa literasi yang artinya siswa belum mampu menjawab soal tes literasi. Metode penelitian yang diterapkan pengembangan model ASSURE yang diawali dengan Student analysis; menetapkan tujuan; pilih metode, media / material, gunakan media \& material; mengaktifkan keterlibatan siswa serta evaluasi \& revisi yang dikembangkan oleh Sharon Smaldino. Adapun studi pendahuluan dilakukan dengan menganalisis siswa kelas V Madrasah Ibtidaiyah (MI) PGM dan Madrasah Ibtidaiyah (MI) An-Nur Cirebon sebagai sampel dan juga melakukan observasi terhadap guru dari kedua sekolah tersebut, maka penelitian ini menghasilkan model SIBELPOLEN untuk pembelajaran IPA. yang terdiri dari: sintaks pengajaran, peran guru, sistem pendukung, dampak pendampingan, dampak instruksional dan merancang rencana pembelajaran yang dapat meningkatkan kompetensi literasi sains siswa sekolah dasar

Kata kunci: siklus belajar; sekolah dasar; lingkungan belajar yang positif

How to Cite: Syamsi, A, M. S. Zulela., Yufiart (2020). Improving Students' Scientific Literacy through the Cyclebased Learning Model. TARBIYA: Journal of Education in Muslim Society, 7 (1), 133-141. doi:10.15408/tjems.v7i1.16941.

Permalink/DOI: http://dx.doi.org/10.15408/tjems.v7i1.16941 


\section{Introduction}

This research focuses more on the development of the Learning Cycle approach (Bybee, 2006) based on the Positive Learning Environment (Swafford, etc.: 2014) as an effort to enhance children's scientific literacy, increase their understanding of basic concepts in science and enable them to internalize the values. The values contained in the scientific process can later be applied in everyday life. (Levy et al., 2016)

This study was carried out because educators in Madrasah Ibtidaiyah Cirebon still used conventional teaching methods and did not optimize the students' scientific literacy. It is expected that later the educators can create a more positive learning environment in support of contextualizing knowledge and practical applications in the field.(Adeniran \& SmithGlasgow, 2010; Keown et al., 2020; Madden et al., 2014; Weih, 2014)

The scientific literacy in this research refers to the understanding of science, which emphasizes not only the concept of science but also how the knowledge is obtained. By perceiving the knowledge acquisition, it is hoped that students can improve the learning outcomes in science subjects, interest in science, and the quality of decision making especially in basic scientific problems that will be faced by students in their environment and everyday life. (OECD, 2014)

Several studies related to the author's study discuss the content of science, but the future of students is also more important (Arikan et al., 2016; Selmer et al., 2014) This research produces science learning methods for Elementary school students which focuses on fundamental problems of science that can directly be applied to the students' daily lives. (Bahng \& Lee, 2017; Weih, 2014)
Several relevant research discusses the integration of the content of science with learning competencies in schools. The basis is increased through the learning cycle approach (Schwartz \& Lederman, 2000) because it has several phases of activities that can be done so that students can play an active role in mastering the competencies that must be achieved during learning. (Wilder \& Shuttleworth, 2004:25-31),

There is also some recent research related to the positive learning environment (Adeniran \& Smith-Glasgow, 2010; Calp, 2020; Kaarby \& Lindboe, 2016; Liao \& Wang, 2015) discusses how to build and develop a positive learning environment to encourage elementary school students to directly involve and play an active role in learning activities, so they are able to preserve their environment. (Bohach \& Meade, n.d.) Some of these conditioning activities and a positive learning environment are also closely related to research done by researchers from Maryville University about the convenience of the Learning Scale to improve a positive learning classroom environment. (Kiener et al., 2014; Mikerova et al., 2018)

In connection with some of those studies, this study has significant differences, such as to: 1) Develop the Science Learning model in the perspective of a Learning Cycle strategy by integrating a positive learning environment approach as efforts to optimize students' "scientific literacy" and 2) contextualize science with practical application in the field so that later it can offer alternative solutions to problems faced by 5th-grade science teachers in Cirebon who still tend to teach science book styleoriented without variation so that it seems monotonous and not create a positive learning environment.

Based on these data findings, the researchers tried to develop a science learning model with learning cycle method based on positive learning environment (SIBELPOLEN) to improve 
students' scientific literacy, and this is in accordance with government programs related to the National Literacy Movement (GLN) which has 3 program derivatives, namely the Movement Family literacy, community literacy and school literacy which includes basic literacy and consists of 6 aspects, namely literacy, literacy, numeracy, science, finance, digital as well as culture and citizenship.

Thus, based on the research focus, the problem of this study is: "How to design a science learning model with a learning cycle based on a positive learning environment to improve the scientific literacy of fifth-grade Madrasah Ibtidaiyah students in Cirebon?”.

\section{Methods}

This research used the Research and Development (R\&D) approach to develop or validate products in education and learning (Borg \& Gall, 1993). The research model developed by the researcher was the integration of Borg and Gall's theory (1993) and the ASSURE development model by Sharon Smaldino. (Smaldino, 2011)

The ASSURE research design, which is a modification of Borg \& Gall's research approach has several stages, and refers to the steps of the ASSURE learning model, see figure 1

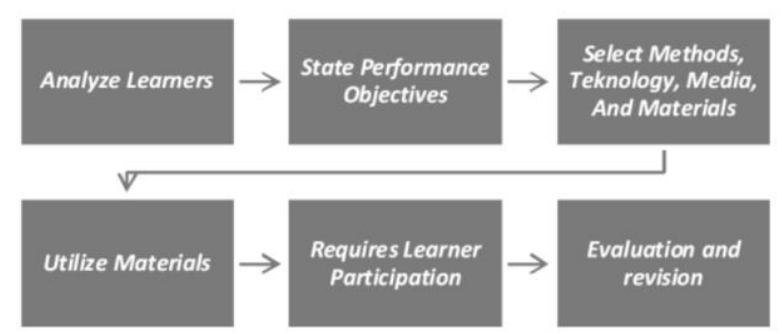

(*translated from the ASSURE model Smaldino, 2011)

Figure 1. Flowchart of the ASSURE

The first stage in the ASSURE model was to analyze grade 5 students at 2 Madrasah Ibtidaiyah, Cirebon, which included students' intellectual abilities, backgrounds, experiences, and skills.

\section{Results and Discussion}

This research is not a comparative study, therefore the results were obtained from the implementation of the SIBELPOLEN model in both schools. The first step before the trial was planning that required the researcher to Analyze learners, State performance objectives, and Select methods, media, and material. Regarding the learner's analysis, the researcher conducted a science test contained literacy practice questions (questions were arranged descriptively in the form of real-life stories) aiming to find out the extent of students' understanding of science. The results of the analysis are as follows table 1.

Table1. The results of the preliminary analysis of students' scientific literacy abilities

\begin{tabular}{|c|c|c|c|c|c|c|}
\hline School & Aspect & $\begin{array}{c}\text { Estudent } \\
s\end{array}$ & Positif & $\begin{array}{c}\text { Percentag } \\
\text { e }\end{array}$ & Negatif & $\begin{array}{c}\text { Percentag } \\
\mathrm{e}\end{array}$ \\
\hline & $\begin{array}{l}\text { Scientific Literacy } \\
\text { Abilities }\end{array}$ & & $\begin{array}{c}\text { Able to answer literacy } \\
\text { questions }\end{array}$ & & $\begin{array}{c}\text { Unable to answer literacy } \\
\text { questions }\end{array}$ & \\
\hline MI PGM & Literacy Test & 21 & 3 & 14,3 & 18 & 85,7 \\
\hline \multirow{2}{*}{$\begin{array}{l}\text { MI An- } \\
\text { Nur }\end{array}$} & Literacy Test & 35 & 5 & 14,3 & 30 & 85,7 \\
\hline & rata-rata & & & 14,3 & & 85,7 \\
\hline
\end{tabular}


After carrying out the scientific literacy test, the researcher also made observations of the methods, media and material that had been given by the teacher as a framework for developing methods, media and student performance sheets (LKPD) and question exercises containing the SIBELPOLEN model to improve scientific literacy that was tried out. At the time of implementing the model SIBELPOLEN. The results of these observations are as follows table 2 .

Table 2. Observation Results of Material, Methods, Media \& Objectives

\begin{tabular}{|c|c|c|}
\hline No & Activities & Results \\
\hline 1 & $\begin{array}{l}\text { Learner } \\
\text { analysis }\end{array}$ & $\begin{array}{l}\text { Knowing the characteristics of } 5 \text { th grade } \\
\text { students in each school, such as cognitive } \\
\text { characteristics and affective characteristics } \\
\text { through theoretical review and discussion } \\
\text { with class teachers and observing directly } \\
\text { in the classroom. }\end{array}$ \\
\hline 2 & $\begin{array}{l}\text { Material } \\
\text { analysis }\end{array}$ & $\begin{array}{l}\text { Following the material in class in } \\
\text { accordance with the learning theme in } \\
\text { curriculum } 2013 \text { and researchers } \\
\text { determine the right strategy in accordance } \\
\text { with SIBELPOLEN and stay in touch } \\
\text { with the material that will or is in } \\
\text { progress in the classroom, so that the trial } \\
\text { runs as it does without disrupting the } \\
\text { scope \& sequence of the material. } \\
\text { Identifying concepts and themes in the } \\
\text { 2nd semester, among other related } \\
\text { environmental themes and ecosystem } \\
\text { themes }\end{array}$ \\
\hline 3 & $\begin{array}{l}\text { Methods } \\
\text { analysis }\end{array}$ & $\begin{array}{l}\text { Knowing the learning methods used, } \\
\text { during } 2 \mathrm{x} \text { pre-research observations, } \\
\text { teachers always use lecture methods and } \\
\text { assignments from the LKS, so that } \\
\text { students are less enthusiastic about } \\
\text { joining the KBM, and researchers } \\
\text { conclude that the process of choosing the } \\
\text { right learning method in accordance with } \\
\text { the classroom and student conditions and } \\
\text { materials is very important. }\end{array}$ \\
\hline 4 & $\begin{array}{l}\text { Media } \\
\text { analysis }\end{array}$ & $\begin{array}{l}\text { During the course of } 2 \mathrm{x} \text { the material in } \\
\text { the class, the teacher used alternative } \\
\text { media only } 1 \mathrm{x} \text { of the two schools, namely } \\
\text { PowerPoints, and because the teacher's } \\
\text { research time asked for a willingness to } \\
\text { give an example of interesting learning so } \\
\text { that the teacher provided the media. By } \\
\text { saving researchers, teachers can use } \\
\text { alternative media available in the } \\
\text { neighborhood when the lack of IT } \\
\text { facilities in the school, only needed } \\
\text { creativity from the teacher alone }\end{array}$ \\
\hline 5 & $\begin{array}{l}\text { Task } \\
\text { analysis }\end{array}$ & $\begin{array}{l}\text { Knowing the assignment by the teachers } \\
\text { based on the LKS that are used as a }\end{array}$ \\
\hline
\end{tabular}

\begin{tabular}{|c|c|c|}
\hline No & Activities & Results \\
\hline 5 & $\begin{array}{l}\text { State } \\
\text { Performan } \\
\text { ce } \\
\text { Objectives }\end{array}$ & $\begin{array}{l}\text { handbook, which is of course only tend to } \\
\text { one aspect of the cognitive aspect, and } \\
\text { researchers formulate the form of bills } \& \\
\text { the more literacy activities that students } \\
\text { will do during the trial learning activities } \\
\text { both individually and in groups } \\
\text { Teachers always convey the learning } \\
\text { objectives to be done on a daily basis, and } \\
\text { this is in line with researchers who also } \\
\text { formulate indicators of achievement of } \\
\text { students ' learning outcomes in water } \\
\text { cycle materials and ecosystem balance } \\
\text { contained in the RPP-based } \\
\text { SIBELPOLEN. }\end{array}$ \\
\hline
\end{tabular}

The results of the observation analysis on science material, methods, media, and learning objectives showed that 5th-grade students demonstrated the typical scope and sequence, as well as the students' character development at that age. However, the teachers applied less varied media that made the students uninterested and less enthusiastic in joining the learning activities in class and less responsive when answering questions. That was proved by the students' inability to link scientific concepts with the environmental context, which actually becomes the foundation of literacy.

After the observation of the learning device, the next step is that the researcher conducts the determination of the planning of Science model study with the students to improve the science literacy that the contents include: a) learning objectives, b) Choose Teaching method, c) Assign learning media, d) Assign learning materials and e) to establish appropriate assessment tools.

After the design and determination of the learning objectives, the next step is to do a model development design that is outlined in the form of a science learning model guideline design with SIBELPOLENand the learning tools, as for the explanation as follows: 


\section{Design of Guidelines for the Science Learning Model with SIBELPOLEN}

The results of this model were guidelines on learning science with SIBELPOLEN equipped with detailed formulation stages. The format of the model guidelines is the introduction and contents. The introduction contains the background of the research and development of the science learning model with SIBELPOLEN to improve the scientific literacy of SD/MI students. Meanwhile, the contents contain theories and characteristics of the SIBELPOLEN model, and instructions to implement the SIBELPOLEN model.

\section{Elements in the Model SIBELPOLEN}

The contents of the sibelpolen model consist of several elements, namely: syntax, social systems, the role of teachers, support systems, instructional impact and accompaniment impact. While the instructions for the implementation of the sibelpolen model contains the stages that must be done by students and teachers, starting from the preparation, implementation and final stages.

This element of the SIBELPOLEN science learning model has several steps and different characteristics according to the elements. The researcher adopts the teaching model of Bruce Joyce and Marsha Weil (2009). The following is the explanation:

\section{Teaching Structure (Syntax Model)}

Syntax describes the structure of a teaching model or the most important stages and how the model is applied together. The syntax of the SIBELPOLEN science learning model is designed by considering the constructivist approach, inquiry and positive psychology. Thus, the syntax of this model is generally divided into 3 stages, namely the initial activity, the core activity and the final activity (feedback). Each of the stages is described as table 3.
Table 3. Syntax Model Science Learning of SIBELPOLEN

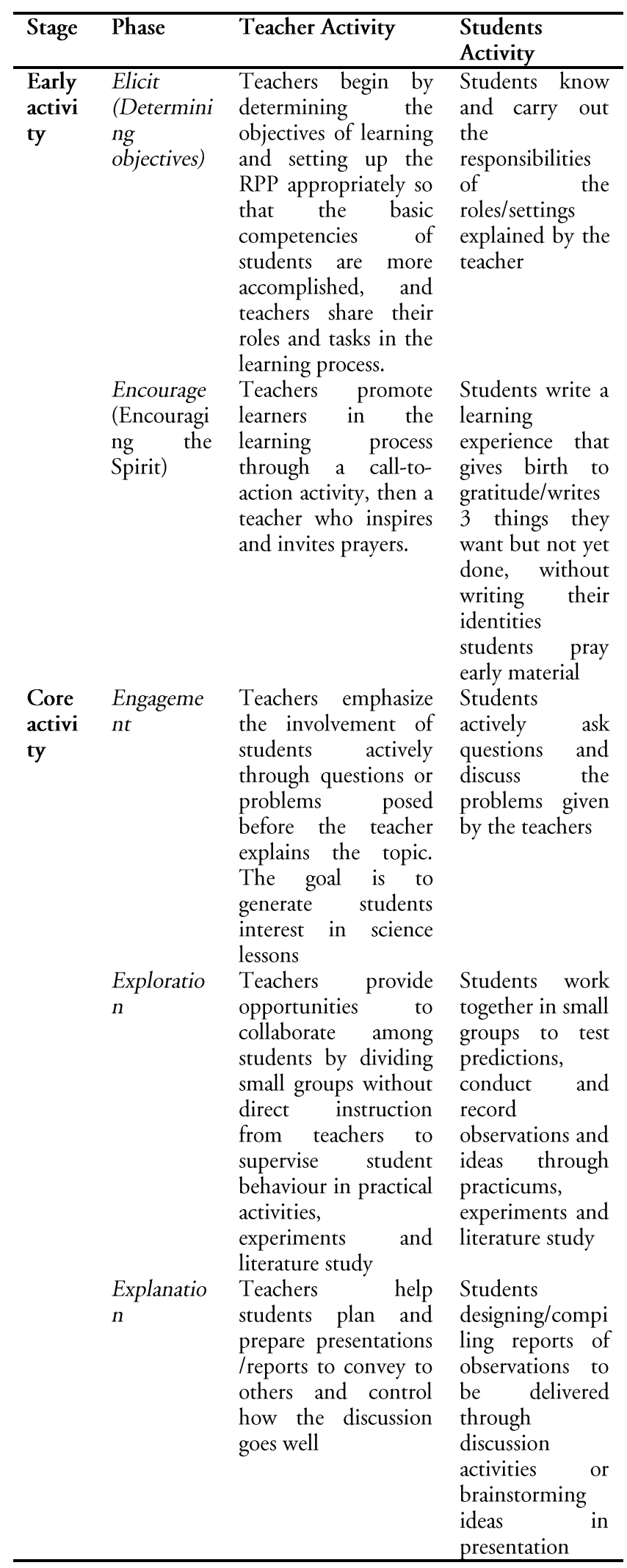




\begin{tabular}{|c|c|c|c|}
\hline Stage & Phase & Teacher Activity & $\begin{array}{l}\text { Students } \\
\text { Activity }\end{array}$ \\
\hline $\begin{array}{l}\text { Final } \\
\text { activi } \\
\text { ty }\end{array}$ & $\begin{array}{l}\text { Enjoyable } \\
\text { Reflection }\end{array}$ & $\begin{array}{l}\text { Teachers invite } \\
\text { students to apply the } \\
\text { concept and skills of } \\
\text { the science process } \\
\text { that has been } \\
\text { acquired by making } \\
\text { questions/inquiries/re } \\
\text { ports according to } \\
\text { the learning } \\
\text { experience that has } \\
\text { been done in the } \\
\text { group aup } \\
\text { Teachers assess the } \\
\text { effectiveness of } \\
\text { phases in core } \\
\text { activities and also } \\
\text { evaluate the content } \\
\text { (scientific by } \\
\text { knowledge), context } \\
\text { (understanding } \\
\text { concepts and } \\
\text { situations), } \\
\text { competencies } \\
\text { (scientific process } \\
\text { skills) and scientific } \\
\text { attitudes of students } \\
\text { (responses, interests, } \\
\text { support and } \\
\text { responsibilities) } \\
\text { Teachers help } \\
\text { students to make fun } \\
\text { reflections and review } \\
\text { the activities that } \\
\text { have been done } \\
\text { through the } \\
\text { invitation to write } \\
\text { some fun things } \\
\text { gained during the } \\
\text { activity, before } \\
\text { students write, the } \\
\text { teacher invites } \\
\text { students to close their } \\
\text { eyes and exhale } \\
\text { regularly } \\
\text { accompanied } \\
\text { music followed by } \\
\text { writing The learning } \\
\text { experience. }\end{array}$ & $\begin{array}{l}\text { Students apply } \\
\text { the concept and } \\
\text { skills of the } \\
\text { science process } \\
\text { that has been } \\
\text { gained in the } \\
\text { form of the } \\
\text { problem, and } \\
\text { solve questions } \\
\text { according to the } \\
\text { learning } \\
\text { experience } \\
\text { Students } \\
\text { conduct } \\
\text { activities in } \\
\text { accordance with } \\
\text { the teacher's } \\
\text { direction but } \\
\text { remain free to } \\
\text { be active in a } \\
\text { working group } \\
\text { of students } \\
\text { completing } \\
\text { assignments } \\
\text { independently } \\
\text { or group }\end{array}$ \\
\hline
\end{tabular}

\section{Social System}

In the SIBELPOLEN model, the social system is interpreted as a learning atmosphere, and the pattern of teacher relationships with students tends to be cooperative, the teacher is considered the initiator of the teaching stages and determining the series of learning activities. Therefore the teacher is responsible for controlling students in a cooperative way. However, students can also have control over the rhythm of activities that occur in class.

The SIBELPOLEN model is very easy to construct. The teacher supervises the course of learning, but open and positive dialogue persists at every stage. Likewise, student interaction must be generated. This model is relatively well structured, where students give more initiative in the teaching process as they gain more experience.

Thus the social system in the SIBELPOLEN model is cooperative, between teachers and students, but the position of the teacher remains the initiator and supervisor of all activities.

\section{The Teacher's Role}

In the first stage, the teacher's task and the role is to select (construct) problem situations, respond to exploratory student inquiries with important information, help learners to focus on their projects, and facilitate discussion between students about the problem situation. Thus as previous research (Rosfiani, O., Akbar, M., Neolaka, 2019) The teacher can be actively involved by helping students to provide an understanding of the objectives of the learning activities carried out and encouraging students to be more creative and think critically through writing positive experiences.

After that, the teacher asks students to collect data and relate it to problem situations. If necessary, the teacher can invite them to experiment and investigate by making new information available to the group and focusing on specific problem events or by asking questions.

During the final stage, the teacher's job is to keep the cycle process directed at the inquiry process itself so that the use of the SIBELPOLEN model is in accordance with an 
open classroom atmosphere, where the teacher's role is to control and monitor teaching.

\section{d) Support System}

This model requires optimal support from students and teachers, facilities, media and learning environment. In the SIBELPOLEN model, the supporting system requires: 1) a set of materials that have been adjusted, 2) a teacher who understands the intellectual process and learning strategies, 3) alternative materials that support the main material, 4) the learning design/implementation plan of the SIBELPOLEN learning, 5) SIBELPOLEN Handbook, 6) Science literacy project sheet, 7) media/learning tools.

\section{Instructional Impact}

The instructional impact is the effect that will directly appear in the learning process in relation to the SIBELPOLEN model that has been applied. The impacts for the students are 1) understanding science material as evidenced by the application of theory in the environment, 2) being able to apply theory in everyday life, 3) having a positive response to the SIBELPOLEN model which requires active, critical, and joyful students' involvement in the learning process.

\section{The Companion Impact}

The Companion Impact is a continuation of the main impact that appears in students and is a continuation of the expected learning objectives. The impacts include: 1) student learning activeness with the inquiry process at the beginning of learning activities, 2) concern for the environment around students, 3) a pleasant learning process with enjoying reflection at the end of learning activities, one of which is by writing a learning experience that is has been done.

\section{Conclusions}

The author concludes that innovation is needed to develop a science learning model which certainly becomes a solution to children's boredom. Students can be happier, more enthusiastic, and eager to learn science and are able to apply the contextually basic theory to their surrounding environments as contained in scientific literacy learning objectives.

The author designed a teaching-learning innovation named SIBELPOLEN model consisted of several phases. The first was Elicit; the teacher began by determining the learning objectives and preparing the lesson plan appropriately. The second was Encourage; the teacher encouraged students to learn by inviting them to write 3 learning experiences that they wanted to share. This activity was carried out at the preliminary stage. The goal was to start the learning activity with positive energy. The third was Engagement; the teacher uplifted students' involvement by asking related questions before explaining the topic. The fourth was Exploration; the students were allowed to work together in small groups without the teacher's surveillance to do observations and explore ideas through a practicum. The fifth was explanation; the students were given ample opportunity to convey the ideas that they have discussed or brainstormed. The sixth was Elaboration; the teacher invited students to apply the scientific concepts that they have been obtained by answering some questions and solving problems related to the learning experience. The seventh was Evaluation; it evaluated the effectiveness of all phases that have been passed. The last phase was Enjoyable Reflection; the students reflected and reviewed activities that have been carried out by writing down some of the pleasant experiences during the learning activity. It aimed to increase students' positive emotions, selfawareness, enthusiasm, and literacy by 
composing a series of pleasant learning experiences.

The SIBELPOLEN model is very easy to do. The teacher only needs to monitor the learning course and open each stage of the cycle with positive dialogue. Likewise, the interaction among students can be raised so that students can be full of the initiative during the teaching process to gain a lot more experience. Thus, the social system in the SIBELPOLEN model is the cooperative relationship between teachers and students, but the position of the teacher remains the initiator and supervisor in all phases of activities.

\section{References}

Adeniran, R. K., \& Smith-Glasgow, M. E. (2010). Creating and Promoting a Positive Learning Environment Among Culturally Diverse Nurses and Students. Creative Nursing, 16(2), 53-58. https://doi.org/ $10.1891 / 1078-4535.16 .2 .53$

Arikan, S., Yildirim, K., \& Erbilgin, E. (2016). Exploring the relationship among new literacies, reading, mathematics and science performance of Turkish Students in PISA 2012. International Electronic Journal of Elementary Education, 8(4), 573-588.

Bahng, E. J., \& Lee, M. (2017). Learning experiences and practices of elementary teacher candidates on the use of emerging technology: A grounded theory approach. International Electronic Journal of Elementary Education, 10(2), 225-241. https://doi.org/10.26822/iejee.201723611 8

Bohach, B. B. M., \& Meade, B. (n.d.). Fifth graders take an interdisciplinary field trip to a farm and learn science and local history in the process. $34-41$.
Borg, Walter R. and Gall, Meredith D. (1993). Educational Research: An Introduction. New York and London; Longman

Bybee, R.W., Taylor, J.A., Gardner, A., Van Scotter, P.,Powell, J.C., Westbrook, A., \& Landes, N. (2006). The BSCS 5E instructional model: Origins,effectiveness, and applications. Colorado Springs:BSCS.

Calp, Ş. (2020). Peaceful and Happy Schools : How to Build Positive Learning Environments. International Electronic Journal of Elementary Education, 12(4), 311-320. https://doi.org/10.26822/iejee. 2020459460

Joyce, B., Weil, M., Calhoun, E. (2009). Models of Teaching (Eighth Edition). New Jersey : Pearson Education Inc.

Kaarby, K. M. E., \& Lindboe, I. M. (2016). The workplace as learning environment in early childhood teacher education: an investigation of work-based education. Higher Education Pedagogies, 1(1), 106120. https://doi.org/10.1080/23752696. 2015.1134207

Keown, S., Carroll, R., \& Raisor, J. M. (2020). Creating a Community of Caring within a. International Electronic Journal of Elementary Education, 12(4), 401-404. https://doi.org/10.26822/iejee.202045946 9

Kiener, M., Green, P., \& Ahuna, K. (2014). Using the Comfortability-in-Learning Scale to Enhance Positive Classroom Learning Environments. InSight: A Journal of Scholarly Teaching, 9, 36-43.

Levy, A. J., Jia, Y., Marco-Bujosa, L., GessNewsome, J., \& Pasquale, M. (2016). Science Specialists or Classroom Teachers: Who Should Teach Elementary Science? Science Educator, 25(1), 10-21. 
Liao, H.-C., \& Wang, Y.-H. (2015). Creating A Positive Learning Environment For Students With English Classroom Anxiety 1. Psychological Reports, 116(2), 631646. https://doi.org/10.2466/11.PR0. $116 \mathrm{k} 21 \mathrm{w} 8$

Madden, L., Peel, A., \& Watson, H. (2014). The Poetry of Dandelions: Merging Content-Area Literacy and Science Content Knowledge in a Fourth-Grade Science Classroom. Science Activities: Classroom Projects and Curriculum Ideas, 51(4), 129-135. https://doi.org/10.1080/ 00368121.2014 .931271

Mikerova, G., Sergeeva, B., \& Mardirosova, G. (2018). Learning Environment Affecting Primary School Student 's Mental Development and Interest. International Electronic Journal of Elementary Education, 10(4), 407-412. https://doi.org/10.26822/iejee.201843813 0

Rosfiani, O., Akbar, M., Neolaka, A. (2019). Assessing Student Social Studies Learning: Effect of Learning Environment, Inquiry and Student Learning Interest. Tarbiya: Journal Of Education in Muslim Society, 6(1), 77583. https://doi.org/10.15408 /tjems.v6i1.11593.

OECD. (2014). PISA 2012 Result in Focus: What 15 - Year - Olds Know and What They can Do with What They Know (Student Performance in Mathematics, Reading and Sciences). Paris: OECD.
Schwartz, R. S., \& Lederman, N. G. (2000). Achieving the Reforms Vision: The Effectiveness of a Specialists-Led Elementary Science Program. Elementary Science Specialists, 100(4), 181-193. https://doi.org/10.1111/j.19498594.2000.tb17255.x

Selmer, S. J., Rye, A., Malone, E., \& Fernandez, D. (2014). What Should We Grow in Our School Garden to Sell at the Farmers ' Market? Initiating Statistical Literacy through Science and Mathematics Integration. Science Activities, 17-32. https://doi.org/10.1080/00368121.2013.8 60418

Sharon E. Smaldino, Dkk, (2011). Instructional Technology \& Media For Learning. Jakarta: Kencana

Weih, T. G. (2014). Student-described engagement with text: Insights are discovered from fourth graders. International Electronic Journal of Elementary Education, 6(3), 395-414.

Wilder, M., \& Shuttleworth, P. (2004). Cell Inquiry: A 5E Learning Cycle Lesson. Science Activities, 41(1), 25-31 